\title{
PEMBUATAN DAN PENGAPLIKASIAN SABUN CUCI TANGAN LIDAH BUAYA DALAM RANGKA PEMBERDAYAAN MASYARAKAT DESA KUNIR DI ERA PANDEMIC COVID19
}

\author{
Amalia Eka Putri \\ Prodi S1 Farmasi Stikes Karya Putra Bangsa Tulungagung \\ Disubmit: 30 April 2021 Diterima: 05 Mei 2021 Diterbitkan: 03 Oktober 2021 \\ Email korespondensi: ekaputriamalia28@gmail.com
}

\begin{abstract}
ABSTRAK
Saat ini masyarakat sedang menghadapi wabah Virus Corona (Covid-19) yang sangat spesifik namun mempunyai efek kompleksitas yang tinggi, bahkan luar biasa, karena ekspektasinya tidak hanya di dunia kesehatan saja namun merambah semua sendi kehidupan manusia. Desa Kunir termasuk desa yang juga mengalami wabah Covid-19, Hal yang dapat masyarakat lakukan untuk memutus rantai penyebaran virus Covid-19 adalah dengan rajin mencuci tangan dengan sabun dan air bersih, serta menggunakan hand sanitizer secara berkala. Lidah buaya memiliki kandungan saponin yang mempunyai kemampuan untuk membersihkan dan bersifat antiseptik. Tujuan setelah pemberdayaan masyarakat desa kunir, diharapkan dapat meningkatkan pengetahuan dan kemampuan dalam memanfaatkan lidah buaya yang ada disekitar tempat tinggal untuk digunakan sebagai sabun cuci tangan. Adapun kegiatan yang dilakukan berupa sosialisasi dan pemberdayaan masyarakat desa kunir dalam pembuatan dan pengaplikasian sabun cuci tangan dari lidah buaya. Terdapat peningkatan pengetahuan dan kemampuan tentang lidah buaya sebagai sabun cuci tangan yaitu 70 \% diperoleh dari kuisioner sebelum dan sesudah dilaksanakan pembelajaran
\end{abstract}

Kata Kunci : sabun cuci tangan, lidah buaya, desa kunir

\section{ABSTRACT}

Currently the community is facing a very specific Corona Virus (Covid-19) outbreak but has a high, even extraordinary complexity effect, because the expectations are not only in the world of health but also penetrate all aspects of human life. Kunir Village is one of the villages that have also experienced the Covid-19 outbreak. What people can do to break the chain of spreading the Covid-19 virus is to diligently wash their hands with soap and clean water, and use hand sanitizers regularly. Aloe vera contains saponins which have the ability to clean and are antiseptic. The goal after empowering the people of turmeric village is expected to increase their knowledge and ability to use aloe vera around the residence to be used as hand washing soap. The activities carried out are in the form of socialization and empowerment of the village community in turmeric in the manufacture and application of hand washing soap from aloe vera. There is an increase in knowledge and abilities about aloe vera as hand washing soap, which is $70 \%$ obtained from questionnaires before and after the learning is carried out.

Keywords: hand washing soap, aloe vera, kunir village 


\section{PENDAHULUAN}

Desa Kunir secara administratif termasuk wilayah Kecamatan Wonodadi, Kabupaten Blitar. Mayoritas masyarakat Desa Kunir berpendidikan akhir SMA/MA yang jumlahnya mencapai 3448 dan SD/MI sebanyak orang 2053. Sebagian besar penduduknya adalah petani, peternak, pedagang, dan sebagian kecil pegawai negeri, guru-guru pendidikan. Sebagaimana kebiasaan dan kondisi sosial di Desa Kunir merupakan daerah yang masih sangat kental dengan kebudayaan daerah. Hal yang paling menonjol adalah banyaknya perayaan-perayaan, khususnya perayaan keagamaan dan juga perayaan adat dan budaya yang masih sangat kental dan merupakan salah satu sarana yang dapat mengundang banyak orang atau khalayak ramai. Kondisi seperti ini sangat penting untuk mendapatkan perhatian pemerintah setempat, karena sangat rentan dengan penyebaran virus Covid-19, dimana telah mengakibatkan 4 warga meninggal akibat virus ini. Corona virus adalah virus RNA dengan ukuran partikel 120-160 nm. Virus ini utamanya menginfeksi hewan, termasuk di antaranya adalah kelelawar dan unta (Susilo et all, 2020).

Corona virus merupakan keluarga besar virus yang menyebabkan penyakit pada manusia dan hewan. Pada manusia biasanya menyebabkan penyakit infeksi saluran pernapasan, mulai flu biasa hingga penyakit yang serius seperti Middle East Respiratory Syndrome (MERS) dan Sindrom Pernafasan Akut Berat/ Severe Acute Respiratory Syndrome (SARS) (KEMENKES RI, 2021). Saat ini masyarakat sedang menghadapi wabah Virus Corona (Covid-19) yang sangat spesifik namun mempunyai efek kompleksitas yang tinggi, bahkan luar biasa, karena ekspektasinya tidak hanya di dunia kesehatan saja namun merambah semua sendi kehidupan manusia. Desa Kunir termasuk desa yang juga mengalami wabah Covid-19, Oleh karena penyebaran virus yang sangat mudah ini, masyarakat dihimbau untuk selalu menjaga kebersihan diri terutama saat melakukan aktivitas di luar rumah. Dengan menjaga kebersihan maka kesehatan tubuh juga akan ikut terjaga, mengingat segala aktivitas kegiatan masyarakat pastilah menggunakan tangan. Hal yang dapat masyarakat lakukan untuk memutus rantai penyebaran virus Covid-19 adalah dengan rajin mencuci tangan dengan sabun dan air bersih, serta menggunakan hand sanitizer secara berkala.

Sabun merupakan pembersih yang dibuat dengan reaksi kimia antara kalium atau natrium dengan asam lemak dari minyak nabati atau lemak hewani. Sabun cair saat ini banyak diproduksi karena penggunaannya yang lebih praktis dan bentuknya yang menarik dibanding bentuk sabun lain saat ini (Lubis \& Maulina, 2020). Cuci tangan dengan air dan sabun efektif untuk menghilangkan kotoran dan debu secara mekanis dari permukaan kulit dan secara bermakna mengurangi jumlah mikroorganisme penyebab penyakit seperti virus, bakteri dan parasit lainnya pada kedua tangan (Desiyanto \& Djannah, 2013). Salah satu bahan yang dapat digunakan sebagai bahan baku alternatif untuk membunuh bakteri pada sediaan sabun cair cuci tangan adalah lidah buaya atau yang lebih sering disebut Aloe Vera (Aloe barbadensis Miller) (Furnawanthi, 2007).

Lidah buaya (Aloe vera (L.) Webb.) memiliki banyak manfaat yakni sebagai sumber penghasil bahan baku untuk aneka produk industri makanan, farmasi, dan kosmetik. Lidah buaya memiliki kandungan saponin yang mempunyai kemampuan untuk membersihkan dan bersifat antiseptik. Saponin larut dalam air dan etanol, tetapi tidak larut dalam eter. Saponin dalam lidah buaya akan menghasilkan busa apabila bercampur dengan air. Zat ini berfungsi sebagai antiseptik. Saponin berfungsi sebagai pembersih dan memiliki sifat-sifat antiseptik. Saponin memiliki karakteristik berupa buih. Sehingga ketika direaksikan dengan air dan dikocok, maka akan terbentuk buih yang dapat bertahan lama. Kadar saponin dalam lidah 
buaya sekitar $5,651 \%$ per 100 gram. Saponin terdiri dari sebuah steroid atau triterpenoid aglycone (sapogenin) yang terkait dengan satu atau lebih gugus oligosakarida. Bagian karbohidrat tersebut terdiri dari pentosa, heksosa, atau asam uronic. Adanya gugus polar (gula) dan non polar (steroid atau triterpene) membuat saponin memiliki permukaan aktif yang kuat yang memberikan banyak manfaat (Gusviputri et all, 2013).

\section{MASALAH}

Berdasarkan tinjauan yang telah dilakukan oleh pengabdi, Mayoritas masyarakat Desa Kunir berpendidikan akhir SMA/MA yang jumlahnya mencapai 3448 dan SD/Ml sebanyak orang 2053. Sebagian besar penduduknya adalah petani, peternak, pedagang, dan sebagian kecil pegawai negeri, guru-guru. Adanya covid-19 membuat ekonomi tidak stabil sehingga mendorong pengabdi untuk memanfaatkan bahan alam yang umum dan banyak ditemukan di desa kunir, dan dapat dimanfaatkan sebagai sabun yang tujuanya bisa dibawa jika bepergian dan melakukan aktivitas, sehingga masyarakat tetap dapat menjaga kebersihan.

Uraian situasi di atas merupakan dasar mengapa perlu adanya solusi cerdas dalam meningkatkan pengetahuan mengenai pembuatan dan pengaplikasian lidah buaya sebagai sabun cuci tangan, yang bisa dilaksanakan di rumah. Melalui program pembuatan dan pengaplikasian sabun cuci tangan lidah buaya dalam rangka pemberdayaan masyarakat desa kunir di era pandemic covid-19. Metode yang digunakan adalah dengan (1) melakukan survei terkait pengetahuan ibu rumah tangga di desa Kunir mengenai pemanfaatan lidah buaya sebagai sabun cuci tangan (2) pengenalan manfaat lidah buaya sebagai sabun cuci tangan (3) Sosialisasi dan pemberdayaan masyarakat desa Kunir dalam cara pembuatan dan pengaplikasian lidah buaya sebagai sabun cuci tangan yang dapat dibuat dan dipergunakan sendiri di rumah (4) evaluasi dan monitoring pemanfaatan lidah buaya sebagai sabun cuci tangan pada ibu-ibu rumah tangga di Desa Kunir.

Harapan pengabdi dari kegiatan pengabdian masyarakat ini adalah masyarakat desa Kunir dapat mengolah lidah buaya sebagai obat tradisional yang dapat dimanfaatkan untuk sabun cuci tangan yang lebih ekonomis dan memiliki efek samping relative lebih kecil dibandingkan dengan penggunaan bahan kimia dan dapat dipergunakan sendiri.

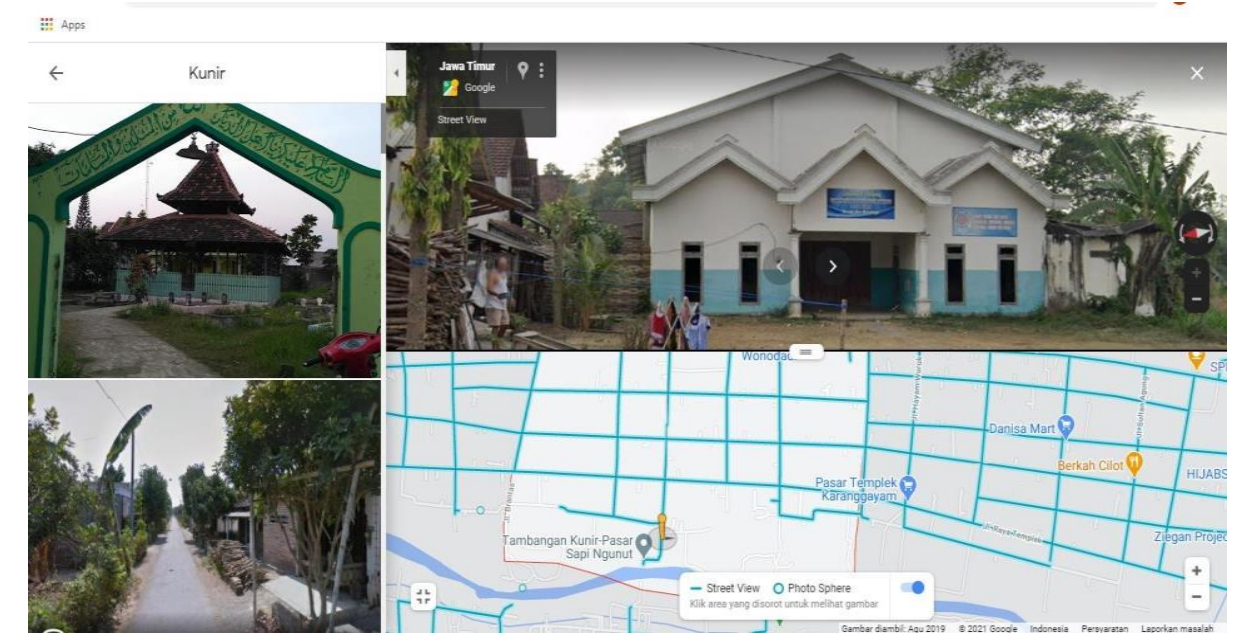

Gambar 2.1 Peta Lokasi Kegiatan Pengbdian Kepada Masyarakat 


\section{METODE}

Program Pengabdian Masyarakat ini dilaksanakan pada Januari - Maret 2021 di Desa Kunir Kecamatan Wonodadi Kabupaten Blitar melibatkan ibu-ibu rumah tangga di desa tersebut. Kegiatan pengabdian kepada masyarakat dilakukan melalui tahapan sebagai berikut:

a) Melakukan survei terkait pengetahuan ibu-ibu rumah tangga di desa Kunir mengenai pemanfaatan lidah buaya sebagai sabun cuci tangan. Tahap survei dilakukan dengan cara analisis situasi yang dilakukan oleh pengabdi dengan terjun langsung ke Desa Kunir dan mengumpulkan informasi permasalahan yang dihadapi mitra, dan memberikan kuisioner seberapa mengerti ibu-ibu rumah tangga di desa Kunir tentang pemanfaatan lidah buaya sebagai sabun cuci tangan.

b) Pengenalan manfaat lidah buaya sebagai sabun cuci tangan.

Melalui program penyuluhan tentang (a) pengenalan cara panen yang baik lidah buaya dengan kualitas yang baik, (b) pengenalan kandungan dan manfaat yang ada pada lidah buaya menggunakan data hasil penelitian (c) pentingnya menjaga kebersihan tangan di era covid-19.

c) Sosialisasi dan pemberdayaan masyarakat desa Kunir dalam cara pembuatan dan pengaplikasian lidah buaya sebagai sabun cuci tangan yang dapat dibuat dan dipergunakan sendiri di rumah.

Melalui program (1) Sosialisasi cara pembuatan sabun cuci tangan dengan menggunakan lidah buaya. Pada program ini mitra berpartisipasi dalam (a) penjadwalan dengan ibu-ibu rumah tangga meliputi: waktu dan tempat penyuluhan, jumlah dan ketentuan umum peserta penyuluhan. (b) Penyebaran leaflet materi penyuluhan (sebagai pengganti undangan). (c) Motivator akan pentingnya hadir dalam acara penyuluhan. Setelah itu dilakukan pemberdayaan warga Desa Kunir dengan cara memberikan Langkah-langkah dalam pembuatan sabun cuci tangan di era covid-19.

d) Evaluasi dan monitoring pemanfaatan lidah buaya sebagai sabun cuci tangan pada ibu-ibu rumah tangga di Desa Kunir.

Guna melihat sampai sejauh mana kemajuan yang didapat ibu-ibu sebelum dan sesudah dilakukan program pembuatan dan pengaplikasian sabun cuci tangan lidah buaya dalam rangka pemberdayaan masyarakat desa kunir di era pandemic covid-19. Tingkat keberhasilan dapat dilihat dari peningkatan pengetahuan ibu-ibu paruh baya dari hasil kuisioner yang telah diberikan sebelum dan sesudah kegiatan pengabdian masyarakat, dengan ketentuan nilai: nilai $1-5$, apabila $50 \%$ dari peserta mendapatkan peningkatan nilai, maka program dinyatakan berjalan dengan baik.

\section{HASIL DAN PEMBAHASAN}

Kegiatan pengabdian kepada masyarakat yaitu melalui program penyuluhan dan pemberdayaan tentang (a) pengenalan manfaat lidah buaya sebagai sabun cuci tangan (b) Sosialisasi dan pemberdayaan masyarakat desa Kunir dalam cara pembuatan dan pengaplikasian lidah buaya sebagai sabun cuci tangan yang dapat dibuat dan dipergunakan sendiri di rumah (c) evaluasi dan monitoring pemanfaatan lidah buaya sebagai sabun cuci tangan pada ibu-ibu rumah tangga di Desa Kunir. Hal ini bertujuan untuk meningkatan ketrampilan ibu-ibu rumah tangga di Desa Kunir Kecamatan Wonodadi, sehingga kualitas kesehatan lebih terjaga dan juga ibu-ibu mulai terberdaya untuk memanfaatkan lidah buaya yang ada disekitar tempat tinggalnya untuk digunakan sebagai bahan pembuatan sabun cuci tangan. Kegiatan pengabdian dilaksanakan di Desa Desa 
Kunir Kecamatan Wonodadi selama 3 bulan, yaitu dimulai pada januari $2021 \mathrm{~s} / \mathrm{d}$ maret 2021.

Melakukan survei terkait pengetahuan ibu-ibu rumah tangga di desa Kunir mengenai pemanfaatan lidah buaya sebagai sabun cuci tangan. Tahap survei dilakukan dengan cara analisis situasi yang dilakukan oleh pengabdi dengan terjun langsung ke Desa Kunir dan mengumpulkan informasi permasalahan yang dihadapi mitra, dan memberikan kuisioner seberapa mengerti ibu-ibu rumah tangga di desa Kunir tentang pemanfaatan lidah buaya sebagai sabun cuci tangan, setelah dilakukan survei ternyata banyak dari mitra yang belum mengetahui tentang manfaat lidah buaya sebagai sabun cuci tangan, hasil kuisioner dapat dilihat pada gambar 4.4. Hal tersebut dibuktikan dengan hasil kuisioner yang menyatakan rata-rata pengetahuan ibu-ibu rumah tangga di desa kunir kurang baik.

Pengenalan manfaat lidah buaya sebagai sabun cuci tangan. melalui program penyuluhan tentang (a) pengenalan cara panen lidah buaya yang baik dengan kualitas yang baik, (b) pengenalan kandungan dan manfaat yang ada pada lidah buaya menggunakan data hasil penelitian (c) pentingnya menjaga kebersihan tangan di era covid-19. dengan metode ceramah pada ibu-ibu rumah tangga desa Kunir (Gambar 4.1)

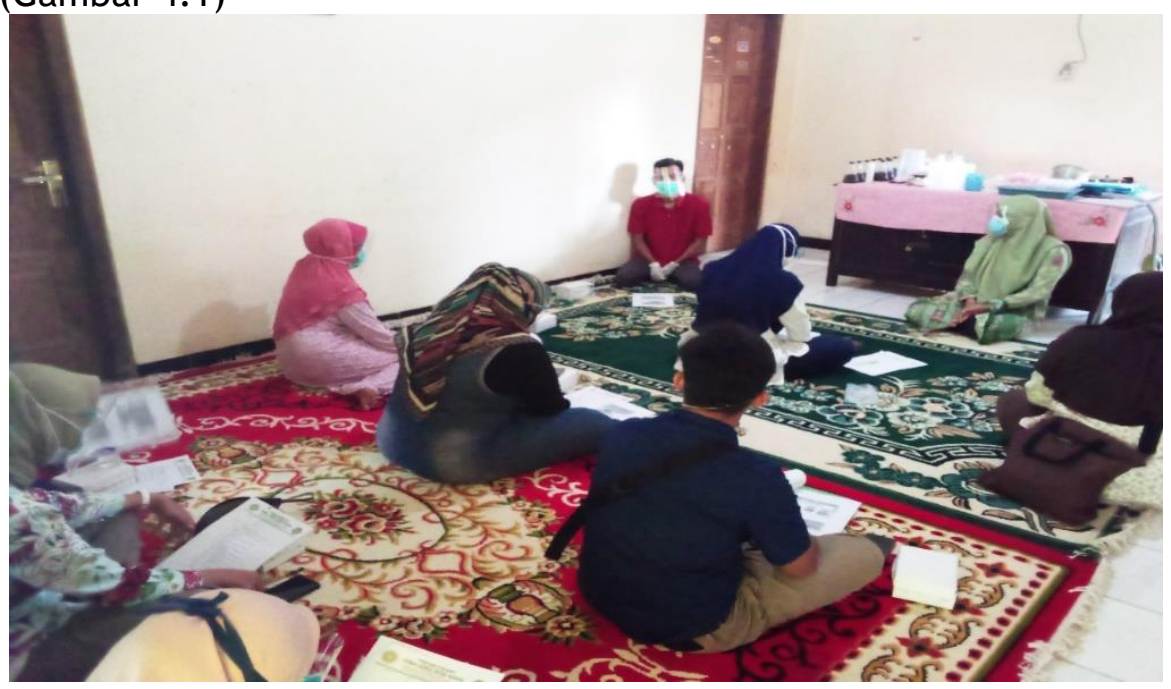

Gambar. 4.1. Pengenalan lidah buaya sebagai sabun cuci tangan

Sosialisasi dan pemberdayaan masyarakat desa Kunir dalam cara pembuatan dan pengaplikasian lidah buaya sebagai sabun cuci tangan yang dapat dibuat dan dipergunakan sendiri di rumah. melalui program (1) Sosialisasi cara pembuatan sabun cuci tangan dengan menggunakan lidah buaya. Pada program ini mitra berpartisipasi dalam (a) penjadwalan dengan ibu-ibu rumah tangga meliputi: waktu dan tempat penyuluhan, jumlah dan ketentuan umum peserta penyuluhan. (b) Penyebaran leaflet materi penyuluhan (sebagai pengganti undangan). (c) Motivator akan pentingnya hadir dalam acara penyuluhan. Setelah itu dilakukan pemberdayaan warga Desa Kunir dengan cara memberikan Langkah-langkah dalam pembuatan sabun cuci tangan di era covid-19.

Cara pembuatan sabun cuci tangan lidah buaya dilakukan dengan metode pengenalan dengan menunjukkan prosedur pembuatan melalui metode ceramah, pemberian leaflet dan praktek secara langsung. Hasil dari pembuatan sabun cuci tangan dari lidah buaya dapat dilihat pada gambar 2, sedangkan cara pembuatan sabun cuci tangan lidah buaya adalah sebagai berikut: Semua bahan yang akan digunakan ditimbang terlebih dahulu sesuai dengan takaran yang dianjurkan. 
Dimasukkan asam stearat sebanyak $3 \mathrm{~g}$ ke dalam gelas beker, kemudian ditambahkan $\mathrm{NaCl}$ sebanyak $1 \mathrm{~g}$ dan $\mathrm{NaOH}$ sebanyak $1,5 \mathrm{~g}$, lalu dilarutkan dengan aquades sebanyak $20 \mathrm{ml}$ di atas penangas sambil diaduk hingga homogen. Ditambahkan EDTA sebanyak 0,5 g dan gliserin sebanyak $10 \mathrm{~g}$ ke dalam gelas beker dan diaduk hingga homogen. Dimasukkan lendir lidah buaya, diaduk hingga homogen. Sabun cair ditambahkan dengan aquades hingga volumenya $100 \mathrm{~mL}$, dimasukkan ke dalam wadah bersih yang telah disiapkan. Pembuatan sabun cair cuci tangan lendir lidah buaya disesuaikan (utami \& denanti, 2018).

Setelah masyarakat Desa kunir mengetahui manfaat lidah buaya sebagai sabun cuci tangan, maka pengabdi melanjutkan kegiatan pengabdian dengan memberikan sosialisasi pembuatan sabun cuci tangan dengan menggunakan lidah buaya. Kegiatan sosialisasi dilaksanakan di salah satu rumah warga Desa kunir, dengan pembagian leaflet dan presentasi, praktek pembuatan sabun oleh pengabdi (Gambar 4.2)

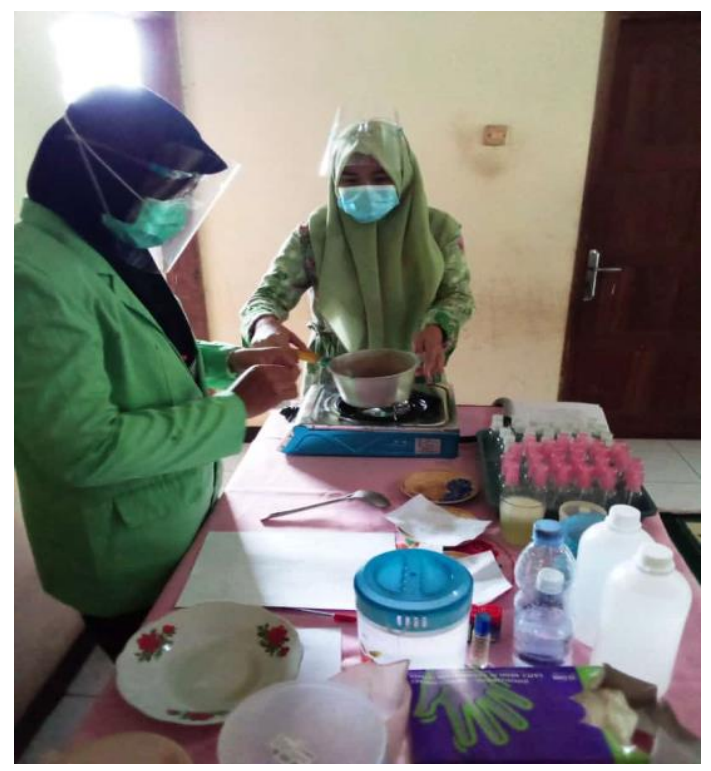

Gambar. 4.2. Pembuatan sabun cuci tangan dari lidah buaya

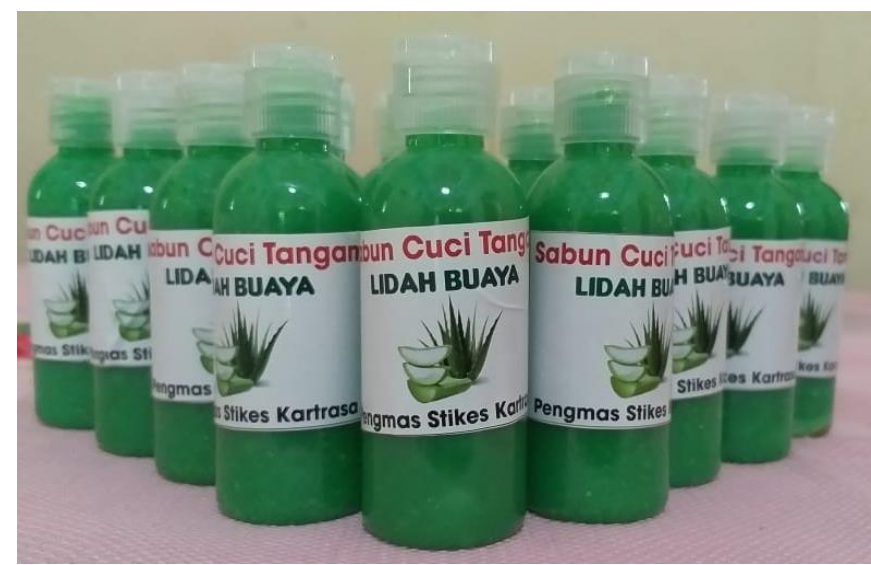

Gambar.4.3. Sabun cuci tangan lidah buaya 
Evaluasi dan monitoring pemanfaatan lidah buaya sebagai sabun cuci tangan pada ibu-ibu rumah tangga di Desa Kunir. Guna melihat sampai sejauh mana kemajuan yang didapat ibu-ibu sebelum dan sesudah dilakukan program pembuatan dan pengaplikasian sabun cuci tangan lidah buaya dalam rangka pemberdayaan masyarakat desa kunir di era pandemic covid-19. Tingkat keberhasilan dapat dilihat dari peningkatan pengetahuan ibu-ibu paruh baya dari hasil kuisioner yang telah diberikan sebelum dan sesudah kegiatan pengabdian masyarakat, dengan ketentuan nilai: nilai 1-100, apabila $50 \%$ dari peserta mendapatkan peningkatan nilai, maka program dinyatakan berjalan dengan baik. Hasil analisis pretest dan postest kegiatan pembelajaran menunjukkan peningkatan nilai ditunjukkan pada Gambar. 4.4 peserta mengalami peningkatan pengetahuan sebesar $70 \%$ ditunjukkan pada Gambar. 4.5, sehingga program pembelajaran dapat disimpulkan sudah berjalan dengan Baik.

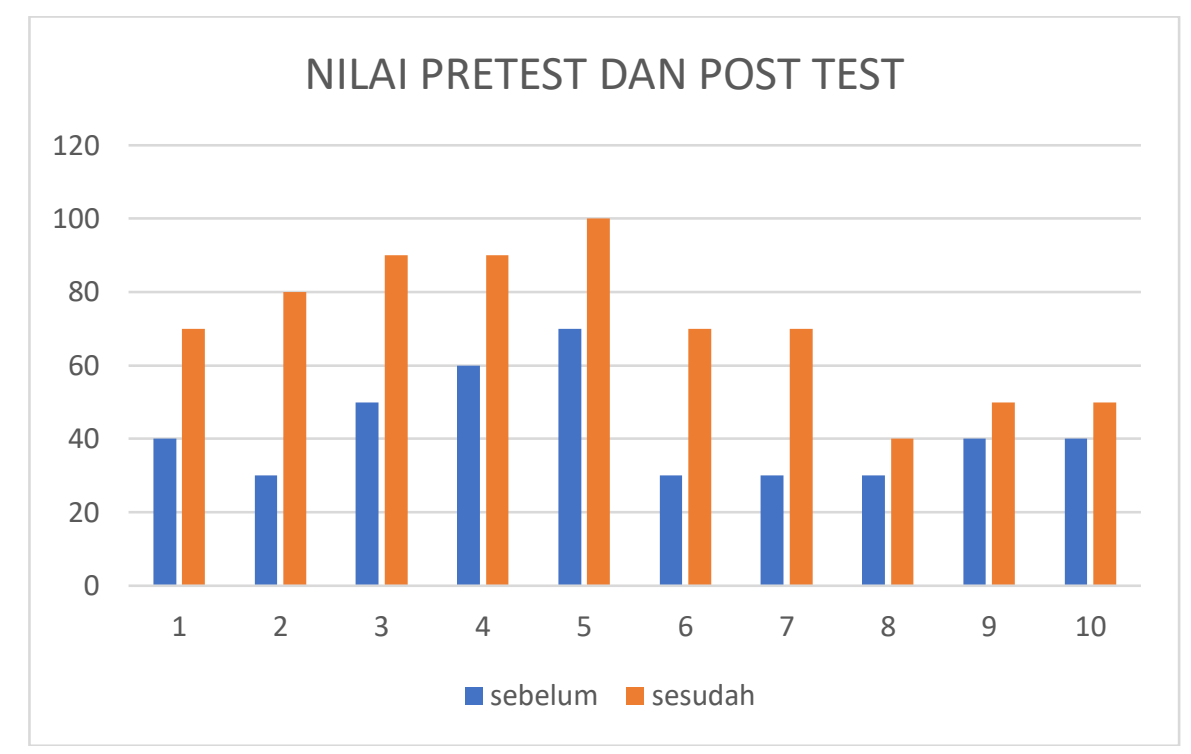

Gambar 4.4 Hasil pretes dan post test sebelum dan sesudah pembelajaran ibuibu rumah tangga desa kunir

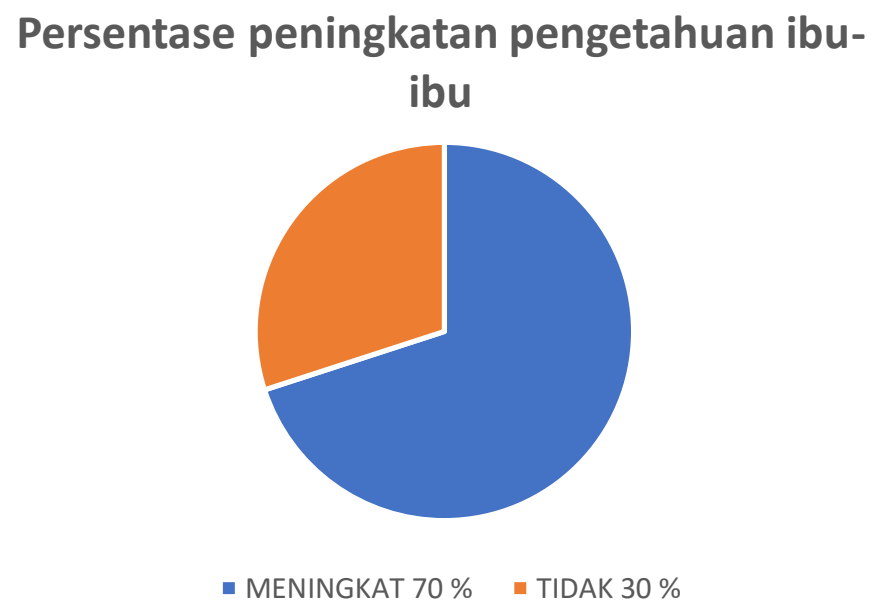

Gambar. 4.5. Presentase peningkatan pengetahuan ibu-ibu rumah tangga desa kunir 
Lidah buaya mengandung senyawa saponin yang mempunyai kemampuan membunuh kuman, emodien antrakuinon yang sebelumnya telah terbukti memiliki aktivitas antimikroba. Antrakuinon bekerja dengan cara menghambat sintesis protein sehinggan bakteri tersebut tidak dapat tumbuh dalam media yang terdapat lendir lidah buaya (Teresya Puteri, 2013). Serta senyawa kuinon sebagai antibakteri dan penghilang rasa sakit. Saponin terdapat pada cairan bening seperti jeli diperoleh dengan membelah batang lidah buaya. Jeli ini mengandung zat antibakteri dan anti jamur yang dapat menstimulasi fibroblast yaitu sel-sel kulit yang berfungsi menyembuhkan luka (Sulaeman, 2008). Selain kedua zat tersebut lidah buaya juga memiliki banyak kandungan kimia dan diantaranya kandungan utama adalah air dan polisakarida (pektin, hemiselulosa, glukomanan, asemanan dan derivat manosa). Selain itu juga mengandung asam amino, lipida, sterol (lupeol, kamposterol dan sitosterol), tanin dan enzim (BPOM, 2008).

Berdasarkan hal tersebut untuk mengetahui apakah sabun cuci tangan tersebut sudah tercampur merata dan dapat berbusa dilakukan pengamatan secara makroskopik yaitu dengan cara mengambil sample ibu-ibu rumah tangga desa blimbing untuk mencoba sabun lidah buaya tersebut dan didapatkan bahwa sabun cuci tangan yang sudah dibuat tersebut tidak mengandung partikel dan dapat berbusa yang dibuktikan dengan cara pengamatan dengan mata telanjang.

\section{KESIMPULAN}

Corona virus adalah virus RNA dengan ukuran partikel 120-160 nm. Virus ini utamanya menginfeksi hewan, termasuk di antaranya adalah kelelawar dan unta. Oleh karena penyebaran virus yang sangat mudah ini, masyarakat dihimbau untuk selalu menjaga kebersihan diri terutama saat melakukan aktivitas di luar rumah. Hal yang dapat masyarakat lakukan untuk memutus rantai penyebaran virus Covid-19 adalah dengan rajin mencuci tangan dengan sabun dan air bersih, serta menggunakan hand sanitizer secara berkala. Lidah buaya memiliki kandungan saponin yang mempunyai kemampuan untuk membersihkan dan bersifat antiseptik dan dapat digunakan sebagai sabun cuci tangan. Setelah dilakukan pengabdian masyarakat di desa kunir dengan melakukan Pembuatan Dan Pengaplikasian Sabun Cuci Tangan Lidah Buaya Dalam Rangka Pemberdayaan Masyarakat Desa Kunir Di Era Pandemic Covid-19. Masyarakat khususnya ibu-ibu rumah tangga yang awalnya belum tahu tentang pemanfaatan lidah buaya sebagai sabun cuci tangan setelah dilakukan pengabdian masyarakat menjadi tahu. Hal tersebut dibuktikan dengan hasil kuisioner sebelum dan sesudah dilaksanakan pembelajaran hasilnya mengalami keniakan $70 \%$.

\section{DAFTAR PUSTAKA}

BPOM RI. (2008). “Buku Acuan Sediaan Herbal” Volume Keempat Edisi Pertama: Jakarta

Desiyanto, F. A., \& Djannah, S. N. (2013). Efektivitas Mencuci Tangan Menggunakan Cairan Pembersih Tangan Antiseptik (Hand Sanitizer) Terhadap Jumlah Angka Kuman. Jurnal Kesehatan Masyarakat (Journal of Public Health), 7(2), 75-82

Furnawanthi. (2007). Khasiat dan Manfaat Lidah Buaya. Kanisius. Jakarta.

Gusviputri, A., Meliana, N., Aylianawati, Indraswati, N., 2013, Pembuatan Sabun Dengan Lidah Buaya (Aloe Vera) Sebagai Antiseptik Alami, Widya Teknik Vol. 12, No. 1, 2013 p.11-21. 
Kementrian Kesehatan Republik Indonesia. (2021). Novel Coronavirus. Diakses dari https://www.kemkes.go.id/folder/view/full-content/structure-faq.html

Lubis, A. W., \& Maulina, J. (2020). Pemanfaatan Ekstrak Kulit Nanas (Ananans comosus L.) Dalam Pembuatan Hand Wash Sebagai Antibakteri, Best Journal (Biology Education Science \& Technology), 3(1), 71

Sulaeman. (2008). Kandungan Saponin pada lidah buaya jenis Barbadensis Miller. Program Diploma Fakultas Teknik, Diponegoro, Semarang. Semarang.

Susilo, A. et al. (2020). Coronavirus Disease 2019: Tinjauan Literatur Terkini Coronavirus Disease 2019: Review of Current Literatures, Jurnal Penyakit Dalam Indonesia, Vol. 7, No. 1, p.45-66

Teresya Puteri. (2013). "Uji Daya Hambat Ekstrak Lidah Buaya (Aloe vera.L.) Terhadap Bakteri Eschericia coli dan Staphylococcus aureus". Fakultas Farmasi Universitas Padjajaran

Utami, S. M., Denanti, I.R. (2018). Uji Efektivitas Antibakteri Sediaan Sabun Cair Cuci Tangan Dari Lendir Lidah Buaya (Aloe Barbadensis Miller) Terhadap Eschericia Coli Dan Staphylococcus Aureus, Edu Masda Journal Vol. 2/No. 2 